\title{
Evaluation of Effect of the Excavator Cycle Duration on its Productivity
}

\author{
Oleg Litvin ${ }^{1, *}$ and Yaroslav Litvin ${ }^{2}$ \\ ${ }^{1}$ T.F. Gorbachev Kuzbass State Technical University, 28 Vesennyaya st., 650000, Kemerovo, Russia \\ ${ }^{2}$ Branch of the JSC "Kuzbassrazrezugol”" Mokhovsky Open Pit Mine, Mokhovo settlement, \\ Belovsky district, 652661, Kemerovo region, Russia
}

\begin{abstract}
Hydraulic excavators currently used at open pit mines, in particular backhoes, are more maneuverable, mobile and have more digging capabilities than rope shovels. This makes them suitable for a variety of conditions: top and bottom digging, loading lower, higher and at the standing level. The variants of mutual arrangement of the excavator and the dump truck, respectively, affect the duration of the excavator cycle, which, in turn, directly affects the productivity of the excavator. This article evaluates changes in the productivity of an excavator, depending on its angle of rotation and options for digging and loading. It is determined that the smaller the swing angle of an excavator, the greater its impact on productivity. Based on the executed calculations relative decrease in productivity (in percent from the most optimum variant) is established. Results of work can be used at planning of open pit mining for the purpose of definition, for example, speed of mining front movement at change of parameters of an excavator face and a type of a digging and loading.
\end{abstract}

\section{Introduction}

The main factors that affect the productivity of the excavation-and-loading complex are the following: condition and reliability of the excavator, its technical characteristics [1-4]; timely delivery of dump trucks, which in its turn depends on the organization of work, quality of road surface [5], supply of spare parts, fuel and energy; quality of the face [6, 15], estimated by its height, conditions of transport approach to the place of loading; the qualification of the excavator operator; condition and category of rocks, which characterizes the labor intensity of rock mass excavation [7-10]; quality of blasting of rocks; thickness of the excavated layer at digging; the bucket filling ratio; length of digging trajectory for full bucket filling [11-13]; width of the cutting edge of the excavator bucket; technological scheme of working off the bench; the place of installation of an excavator when working off the bench [14]; the load capacity of the dump truck [16]; the angle of rotation of the bucket during loading [17-20]; loading method [21]; the length of the worked-out rock block [22]; coefficient of fragmentation of rock in the excavator bucket; climatic conditions [23].

\footnotetext{
*Corresponding author: litvinoi@kuzstu.ru
} 
Since in the layered working out of the benches (usually in 3 layers) it is possible to have different location of excavator and dump truck. When working out the top layer, the excavator can work in two ways: with digging at the installation level and with the bottom (low) digging. Accordingly, the dump truck can be installed at the excavator level or below it [20].

When working out the middle layer, the excavator can work with upper digging, bottom digging or with digging at the installation level. Accordingly, the dump truck can also be installed in three different ways - above the level of the excavator, below it or at the same level.

Finally, when working on the bottom layer, the excavator dig either above the installation level or at the same level. The dump truck is installed in the same way [21-22].

\section{Materials \& Methods}

To a great extent the productivity of the backhoe of all these factors is affected by the duration of the excavating cycle. In general, excavator operation cycle was proposed by prof. N.G. Dombrovsky and later was used by other authors for excavator productivity study. Cycle stages are the following:

- bucket unloading;

- turning and lowering of the bucket from the dump truck body to the place of bucket filling in the face of the worked-out layer;

- bucket filling;

- turning and raising the bucket to the level of unloading above the dump truck body;

- installation of the bucket over the unloading place according to the dump truck loading passport.

In [6] the calculation of the excavator cycle duration is carried out, which consists in the following:

- average unloading time $t_{\text {unload }}$ with a high confidence grade is approximated by the formula: $T_{\text {unload }}=2.6 \times \sqrt[3]{B}$, where B is a backhoe bucket capacity.

- the length of time for turning and lowering the bucket from the dump truck body to the place where the bucket is filled at the bottom of the worked-out layer. In most cases this operation is performed simultaneously and its duration is proportional to the length of bucket trajectory as it moves from the dump truck body to the place of the next filling and inversely proportional to the bucket linear speed:

$$
T_{\text {low }}=\frac{1}{v_{\text {low }} \cdot \sqrt{\left[\left(\frac{\pi \cdot \alpha_{\text {turn }}\left(2+R_{\text {dig }}\right)}{360}\right)^{2}+\left(c_{2} \cdot h_{l}+h_{d t}+2\right)^{2}\right]}} ;
$$

where: $v_{\text {low }}-$ the linear speed of the bucket during its turning and lowering (in average $v_{\text {low }}=1 \mathrm{~m} / \mathrm{sec} ; \alpha_{\text {turn }}$ - rotation angle of the excavator, deg.; $R_{\text {dig }}-$ the digging radius of the backhoe, $\mathrm{m} ; h_{l}$ - excavated layer thickness, $\mathrm{m} ; c_{2}-$ the specification of dump truck position ( $c_{2}=0$ for lower position, $c_{2}=1$ for upper position); $h_{d t}-$ the height of the dump truck body, $\mathrm{m}$.

The time for bucket lifting and its rotation is determined by a similar dependence: 


$$
T_{\text {lift }}=\frac{1}{v_{\text {lift }} \sqrt{\left[\left(\frac{\pi \cdot \alpha_{\text {turn }} \cdot\left(R_{\text {dig }}-0.84 \cdot h_{l}+2\right)}{360}\right)^{2}+\left(c_{2} \cdot h_{l}+h_{d t}+2\right)^{2}\right]}}
$$

where: $v_{\text {lift }}-$ the speed of the bucket when it is lifted and turned.

Based on natural observations, the duration of the bucket filling is approximated with a confidence grade of 0.97 with the following dependence (5):

$$
T_{f i l}=4.2 \cdot E^{0.45}\left[1+2 \cdot \sqrt{\left(0.25-\frac{h_{l}+c_{2}}{R_{d i g}}\right)^{2}}\right] .
$$

Therefore, the total duration of the excavator's technological cycle consists of the sum of the considered constituent elements (6):

$$
T_{c}=T_{u n}+T_{\text {low }}+T_{\text {lift }}+T_{\text {fil }}+T_{\text {pos }},
$$

where $T_{p o s}$ - the time of positioning of the bucket over the dump truck body in accordance with the loading certificate $\left(T_{p o s}=1.0-1.5 \mathrm{sec}\right)$.

\section{Results and Discussion}

Since the technical cycle duration and productivity of the excavator for the same conditions of installation of dump truck for loading do not change, then we'll build graphs of the dependence of cycle duration and annual productivity from the angle of rotation of the excavator for the second (medium) layer of mined bench, where all the options of location of transport for loading (Fig.1, Fig. 2):

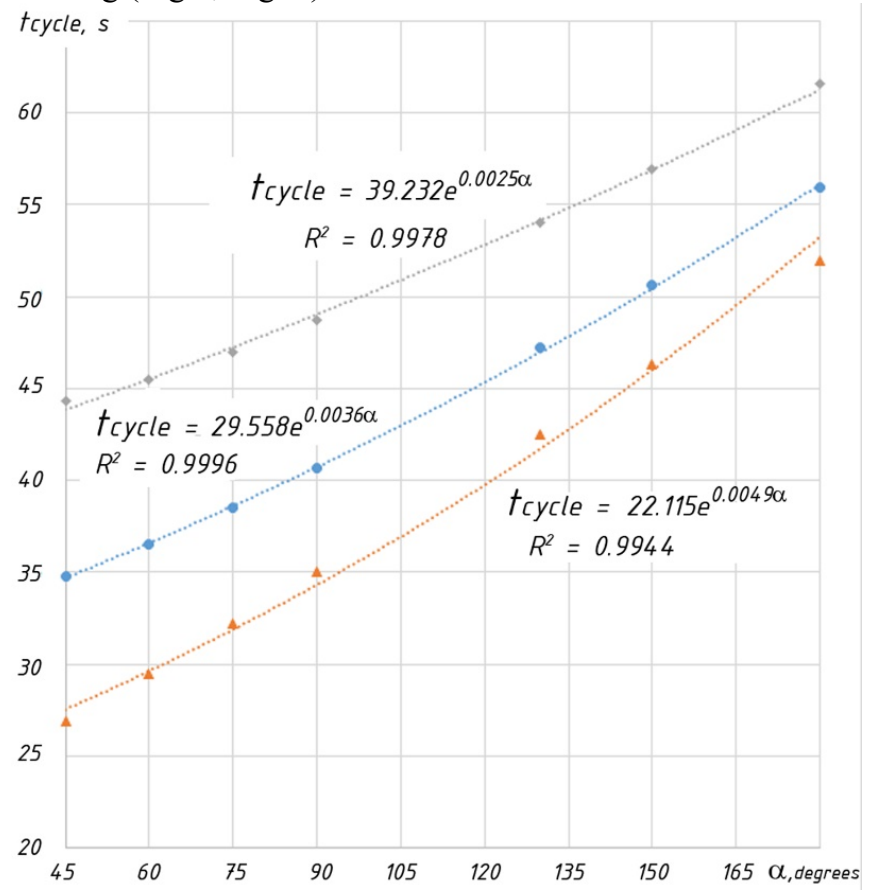

Fig. 1. Dependences between cycle time $t_{\text {cycle }}(s)$ and angle of excavator rotation for upper loading, installation level loading and lower level loading (upper, middle and lower curve, respectively). 


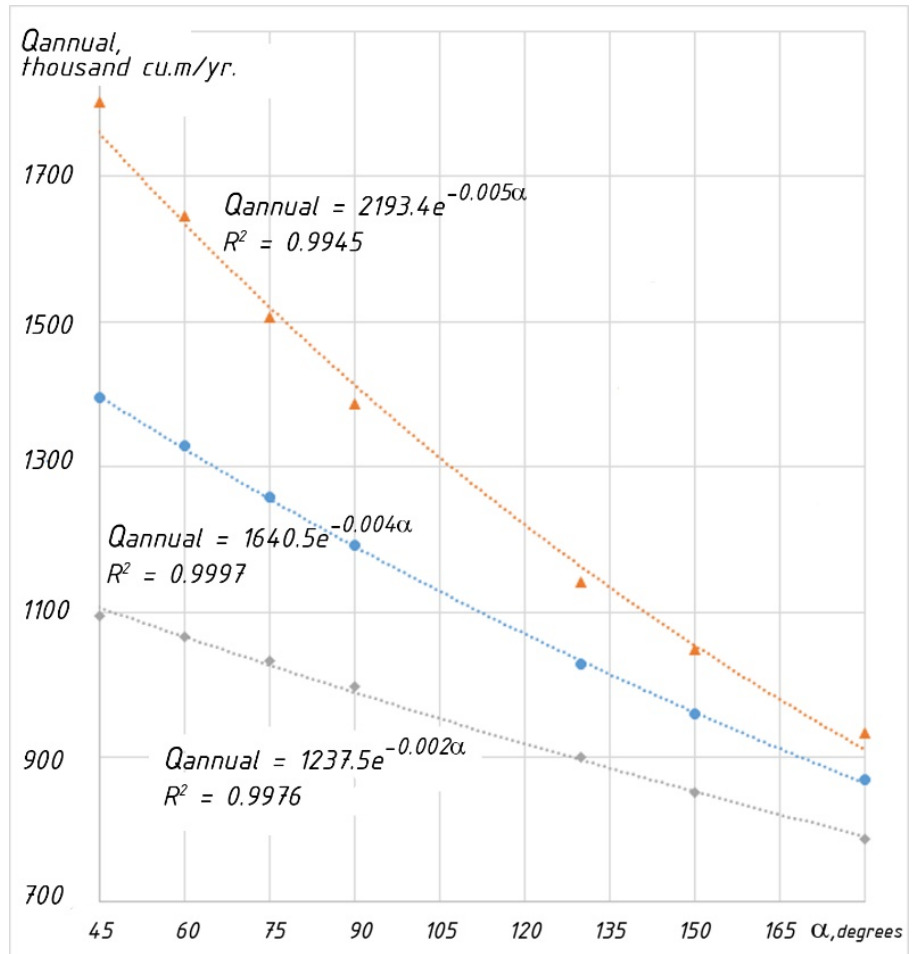

Fig. 2. Dependences between annual capacity of excavator and angle of its rotation for upper loading, installation level loading and lower level loading (lower, middle and upper curve, respectively).

The graphs show that the highest productivity takes place when loading the rock mass below the excavator installation level, which is explained by the lowest bucket lifting height.

The graphs show that with a smaller angle of excavator rotation for unloading the difference in annual capacities will be much greater than with a larger angle. Apparently, this is explained by the fact that with a small angle of rotation a significant part of the time used for lifting and turning the bucket, it takes lift. Accordingly, at a large angle of rotation time for bucket elevation is a relatively small value, weakly affecting the total cycle time.

\section{Conclusion}

Versatility of backhoes consists in performance of a wide range of mining operations (coal seam excavation, trenching, overburden bench mining, etc.) that allows to develop coal deposits with complex mining and geological conditions of seams occurrence.

Excavator and dump truck mutual installation options affect the operational performance of the excavator. The highest productivity of hydraulic backhoes is achieved when installing a dump truck below the excavator installation level.

When developing overburden by backhoes it is necessary to take into account the factors directly affecting the productivity of the excavator, one of which is the duration of the technological cycle.

Excavator rotation angle has a greater influence on productivity at values from 45 to $90^{\circ}$ due to the lack of possibility of combining operations during loading of dump truck. 


\section{References}

1. Z. Ren, J. Wang, J. Chen, J. Zhang, J. Liu, Y. Liang, H. Sun, Mathematical Problems in Engineering 2019, 9846305 (2019)

2. M. Krynke, R. Ulewicz, Transportation Research Procedia 40, 745 (2019)

3. R. K. Juraboevich, Int. J. of Scientific and Technology Research 9:3, 2007 (2020)

4. R. Sobolevskyi, V. Korobiichuk, V. Levytskyi, V. Pidvysotskyi, O. Kamskykh, L. Kovalevych, Rudarsko Geolosko Naftni Zbornik 35:1, 123 (2020)

5. Z. Šimková, M. Cehlár, H. Pavolová, Acta Montanistica Slovaca 21, 208 (2016)

6. A. V. Strelnikov, Journal of Mining and Geotechnical Engineering 4:7, 4 (2019). DOI: 10.26730/2618-7434-2019-4-4-29

7. D. M. Dubinkin, V. Yu. Sadovets, G. O. Kotiev, A. V. Kartashov, Journal of Mining and Geotechnical Engineering 4:7, 50 (2019). DOI: 10.26730/2618-7434-2019-4-5066

8. V. Kolesnikov, O. Litvin, J. Janočko, A. Efremenkov, E3S Web of Conferences 21, 01031 (2017)

9. M. Tyulenev, O. Litvin, S. Zhironkin, M. Gasanov, Acta Montanistica Slovaca 24:2, 88 (2019)

10. M. A. Tyulenev, S. A. Zhironkin, O. I. Litvin, E. A. Tyleneva, O. V. Zhironkina, S. O. Markov, Geotechnical and Geological Engineering 35:5, 2065 (2017)

11. M. Tyulenev, O. Litvin, M. Cehlár, S. Zhironkin, M. Gasanov, Acta Montanistica Slovaca 22(3), 296 (2017)

12. A. Strelnikov, S. Markov, L. Rattmann, D. Weber, E3S Web of Conferences 41, 01003 (2018)

13. O. Litvin, V. Makarov, A. Strelnikov, E. Tyuleneva, E3S Web of Conferences 105, 010241 (2019)

14. E. A. Tyuleneva, Yu. V. Lesin, Ya. O. Litvin, Journal of Mining and Geotechnical Engineering 1(4), 35 (2019). DOI: 10.26730/2618-7434-2019-1-35-49

15. A. V. Strelnikov, Journal of Mining and Geotechnical Engineering 3:6, 4 (2019). DOI: 10.26730/2618-7434-2019-3-4-20

16. L. I. Kantovich, O. I. Litvin, A. A. Khoreshok, E. A. Tyuleneva, Mining Informational and Analytical Bulletin 2019, 4, 152 (2019)

17. A. Strelnikov, M. Radek, M. Stolz, R. Rosenberg, E3S Web of Conferences 41, 01027 (2018)

18. A. V. Katsubin, A. A. Fedotov, Journal of Mining and Geotechnical Engineering 3:6, 60 (2019). DOI: $10.26730 / 2618-7434-2019-3-60-75$

19. E. I. Vasil'ev, V. F. Kolesnikov, Soviet Mining Science 5:5, 523 (1969)

20. O. Litvin, M. Gasanov, S. Zhironkin, M, Tyulenev, Int. J. Of Mining and Mineral Eng. (to be published)

21. V. Kolesnikov, A. Katsubin, V. Martyanov, A. Dobrov, E3S Web of Conferences 105, 010231 (2019)

22. S. M. Miliy, Journal of Mining and Geotechnical Engineering 1:8, 45 (2020) DOI: $10.26730 / 2618-7434-2020-1-45-73$

23. I. N. Klement'eva, D. A. Kuziev, Mining Informational and Analytical Bulletin 2, 123 (2019) 